\title{
The Labour Relations Act and changes to the structure of bargaining
}

\author{
Greg Wood*
}

This article discusses the impact of inflationary expectations and outcomes on the 1987-88 wage round, the first under the Labour Relations Act 1987.

It argues that any trade-off between moderate wage settlements and the retention of the national award system for at least another year has worked to the advantage of unions because of the sharp fall in inflation since September 1987. Since real wages have in general at least been maintained under negotiations which basically took place within the national award system, the pressures for major structural changes to the bargaining system are correspondingly less than if real wages had, as expected, declined.

\section{Introduction}

This article addresses the question of changes to the structure of bargaining between employers and unions following the passage of the Labour Relations Act 1987. Firstly the effect of the Labour Relations Act's provisions in respect of bargaining arrangements are described and linked with the policy objectives of the Government. The strategies available to and taken up by the parties in the 1987-88 wage round are then canvassed. The hypothesis is made that both unions and employers appeared prepared to accept that the national award system would continue to operate in this wage round, but that any settlements reached would have to be set at a moderate level.

Results from data collected on settlements in the wage round are examined to assess the extent of changes to the structure and nature of bargaining. The impact of inflation and inflationary expectations over this period are then analysed. It is argued that any tradeoff between moderate wage settlements and the retention of the national award system for at least another year has worked to the advantage of unions because of the sharp fall in inflation since September 1987. Since, overall, workers' real wages have at least been maintained under negotiations which generally took place within the national award system, the pressures for major reforms to the bargaining structure are correspondingly less than if real wages had, as expected, declined.

The article does not attempt, however, to predetermine the extent or form of structural change that may occur in the bargaining system. Analysis at the industry or firm level will be vital in determining the nature and effect of the structural changes that do (or do

Assistant Director, Industrial Relations Division, Department of Labour. The views expressed in this article are those of the author, not those of the Department of Labour. 
not) occur. The article does not, however, attempt to analyse the changes in bargaining that have already occurred in some industries and occupations.

\section{The effect of the Labour Relations Act}

The overall objective of the Labour Relations Act 1987 is "to encourage the development of effective union and employer organisations which:

\section{can operate independently of legislative support; and}

can negotiate awards and agreements which are relevant to the industry or workplace in which they apply, and which are adhered to."1

In relation to the negotiation of awards and agreements, i.e. the structure of bargaining, the Act provides for workers' terms and conditions of employment to be fixed by a single set of negotiations.

In order to ensure this, the union party to an award must choose, on behalf of its members, which employers (if any) are to be negotiated with separately, outside of the award. Where such a choice is made, those workers are excluded from the coverage of any ensuing award and may only be brought back within any subsequent award negotiations by agreement with the employer. In addition, where an award does apply to an employer, any separate agreement reached with that employer cannot be registered and the employer in that case may apply for an exemption from the award. Such an exemption applies for at least the duration of that and the subsequent award and, until the parties agree otherwise, for every subsequent award. The only major exception to this regime is that a composite agreement, which relates to settlements between several unions (the minimum numbers required are defined in the Act) and an employer or employers, may be negotiated and registered at any time.

In essence, this system was developed with the intention of removing "second tier" bargaining from within the framework of the Act. The 'single set of negotiations' principle was designed therefore to ensure that once a settlement had been reached covering certain unions and employers, that settlement under the Act would be adhered to for its duration and any further arrangements that were negotiated would not be collectively enforceable. Composite agreements are provided for in order to promote multi-union bargaining, as such bargaining provides the capacity to greatly limit the number of sets of negotiations any one employer may be involved in.

However, the Act does not serve to impose any particular form of bargaining. This is seen to be determinable by the parties themselves, and this intention is reinforced with the provision of voluntary rather than any form of compulsory arbitration. Thus, settlements may cover the full structural range from national awards with "blanket coverage" to plant agreements. It is the union which makes the initial choice, for each employer, whether or not to pursue separate negotiations with them outside the award. However, as there are no constraints on the matters parties may negotiate about under the Act and negotiations need not necessarily lead to final agreement, the above power is to some extent counterbalanced by the ability of either party to exclude any employers and workers from the coverage clause of any award or agreement.

Further, the parties need not use the provisions of the Labour Relations Act at all. There is nothing to stop the parties from negotiating settlements that remain unregistered 
and thus outside the regime put in place by the Act. Pass-on agreements attached to awards and agreements as memoranda are examples of this approach.

\section{Strategies available to the parties}

The 1987/88 wage round was the first wage round to be negotiated under the new legislation. This in itself was likely to generate conservative responses from the parties. The likelihood of such responses was further strengthened by the continuing high degree of uncertainty over the state of the economy and its future. On the other hand, the problems of economic stagnation in certain sectors and rapidly rising unemployment must have exerted some pressure on the parties to consider new options for the structure of bargaining, other than simply maintaining the national award system.

It is difficult to generalise and try to present a union and an employer perspective to this wage round. Many employers such as those in the hotel industry and many small employers, for instance, support the retention of the national award system, while others, such as those represented on the Business Roundtable, strongly advocate the development of decentralised bargaining at the workplace level. Similarly, while unions strongly support the principle of the national award system there are some unions to whom, because of the particular circumstances affecting their industry or occupation, the maintenance of the national award is not of paramount significance in practice. This fact highlights another major issue. That is, it is unlikely that a centralised or global solution as to how bargaining structures might be rearranged can be imposed, if awards and agreements are to be relevant to the industry or workplace in which they apply. Necessarily, these matters are best left to those unions and employers directly affected by each set of negotiations. Therefore, the major determinant of structural change will be the actions of those groups, not the actions and policies of the central employer and union organisations. In this light, major attention is likely to be focussed, in terms of structural changes agreed to in this round, on the transport industry, parts of the automotive assembly and timber industries, perhaps the meat freezing industry (where the fate of the national award remains uncertain), and to a lesser extent the engineering industry.

However, in the present system which has largely been relativity-driven, in which the pattern for the wage round is effectively set by a handful of key awards negotiated early in the piece, leaving little scope for negotiation in those that follow, there is likely to be more emphasis on inter-dependent, co-ordinated or centralised strategies. On the employer side, advocacy for the large majority of awards is provided by the Employers Federation. On the union side, although each union is responsible for its own advocacy and the Federation of Labour recommended that a common level of claims was not necessary this round, their emphasis on historical relativities and the national award system made common outcomes, if not common approaches, highly probable. Therefore, I intend to assess the strategies and outcomes of the 1987/88 wage round from an 'employer' and 'union' perspective, taking into account the above caveats.

Before the wage round the Federation of Labour circulated the chart figured below, on union options under the new legislation. It signals that unions consider they have most to gain from retaining the national award, especially if it were to contain company specific schedules or "pass-on" clauses as a means of retaining existing second-tier agreements, and from composite agreements. It also identifies agreements allowing the employer exemption from the award and agreements where the union has nominated an employer out of the award talks for separate negotiations, which are both seen as destructive to the national award system, as being the most disadvantageous options for unions.

On the other hand, at the 1987 Tripartite Wage Conference, in their summary 'The 1987 Wage Round in Context of the Economy and the Labour Relations Act,' the Employers Federation stated: 
AWARD/AGREEMENT OPTIONS UNDER LABOUR RELATIONS ACT

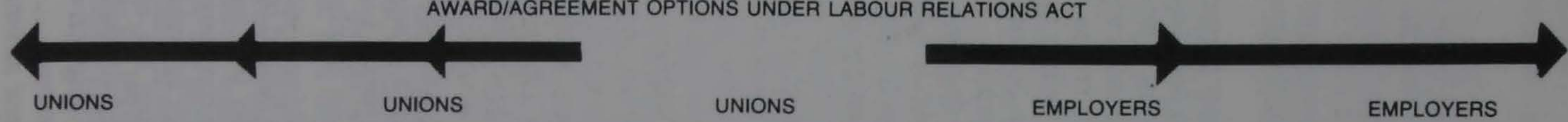

\begin{tabular}{|c|c|c|c|c|}
\hline NATIONAL AWARD & $\begin{array}{l}\text { COMPOSITE AGREEMENT } \\
\text { (S.166) }\end{array}$ & $\begin{array}{l}\text { COMPOSITE AWARD } \\
\text { (S. 137) }\end{array}$ & AGREEMENTS (S. 164) & AGREEMENTS (S. 152) \\
\hline $\begin{array}{l}\text { + Company specific schedules } \\
\text { or } \\
\text { "pass on clauses" } \\
\text { as means of retaining existing } \\
\text { second-tier agreements. }\end{array}$ & $\begin{array}{l}\text { between several unions \& } \\
\text { employers on one site } \\
\text { or on several sites with several } \\
\text { employers. }\end{array}$ & $\begin{array}{l}\text { initiated jointly by } \\
\text { several unions or } \\
\text { several employers. }\end{array}$ & $\begin{array}{l}\text { where union has nominated an } \\
\text { employer out of the award talks } \\
\text { for separate negotiations, ie } \\
\text { before the conciliation council is } \\
\text { formed. }\end{array}$ & $\begin{array}{l}\text { where union or group of workers } \\
\text { has not nominated an employer } \\
\text { out of the award talks but } \\
\text { initiates separate negotiations } \\
\text { anyway. }\end{array}$ \\
\hline needs two or more employers. & $\begin{array}{l}\text { needs } 50 \% \text { of unions or five } \\
\text { unions (involved in the } \\
\text { undertakings), whichever is the } \\
\text { lesser, } \\
\text { and one employer. }\end{array}$ & $\begin{array}{l}\text { needs two or more unions } \\
\text { and two or more employers. }\end{array}$ & $\begin{array}{l}\text { needs only one employer and } \\
\text { one union. }\end{array}$ & $\begin{array}{l}\text { one employer } \\
\text { one union or a group of } \\
\text { workers. }\end{array}$ \\
\hline $\begin{array}{l}\text { Registered under LRA. } \\
\text { Enforceable under LRA. }\end{array}$ & $\begin{array}{l}\text { Registered under LRA. } \\
\text { Enforceable under LRA. }\end{array}$ & $\begin{array}{l}\text { Registered under LRA. } \\
\text { Enforceable under LRA. }\end{array}$ & $\begin{array}{l}\text { Registered under LRA. } \\
\text { Enforceable under LRA. }\end{array}$ & $\begin{array}{l}\text { Not registerable under LRA. } \\
\text { Not enforceable under LRA. } \\
\text { Have to be enforced in civil } \\
\text { courts. }\end{array}$ \\
\hline Obviously retains the award. & $\begin{array}{l}\text { Automatic return to award if } \\
\text { withdrawn - has negative effect } \\
\text { on national award and wage } \\
\text { rates. }\end{array}$ & $\begin{array}{l}\text { has negative effect on national } \\
\text { award and wage rates. } \\
\text { Plantenterprise union. }\end{array}$ & $\begin{array}{l}\text { lose award coverage. } \\
\text { May return to award coverage if } \\
\text { employer agrees. } \\
\text { Destructive to national award } \\
\text { system. }\end{array}$ & $\begin{array}{l}\text { Employer may apply for a } \\
\text { exemption from award. } \\
\text { Destructive to national award } \\
\text { and union. }\end{array}$ \\
\hline
\end{tabular}


In approaching the wage round employers have two basic options.

The first is to accept the perpetuation of the existing national award system and suffer the inevitable consequences of business closures and further job losses.

The second is to say "no" and take initiatives towards workplace and/or true industry bargaining in the interests of stability, job retention and prospective growth.

To say "no" will, under present union attitudes, meet major resistance and cause disruption to the lives of workers and their families, our fragile markets and to the economy as a whole....

If the action of Government and the attitudes of the FOL/CSU require, employers will pick up one of these unpalatable options.

The Employers Federation have also consistently stated that any changes in award levels must be sustainable by the lower quartile of industry.

It appears clear from the results of the wage round, as analysed later, that unions in general pursued the national award system and the employers picked up the first of their "unpalatable" options. However, as analysed below, it also seems clear employers were prepared to accept a delay in any general moves towards changing the bargaining structure in this round, but only provided wage settlements could be sustained by the lower quartile of industry. This effectively meant a continuation of their 1986 strategy which led to average settlements below the recorded level of inflation over the term of awards and voluntary collective agreements. Such a solution, whether the result of explicit or implicit strategies, is in the nature of a trade-off and the results of that trade-off are also analysed below.

\section{Results of the $1987-88$ wage round}

It may be apposite to note that the fact that there is an identifiable 1987-88 wage round and that it appears there will similarly be a 1988-89 round, are indications in themselves of little change in the system.

A statistical analysis of settlements advised to the New Zealand Employers Federation ${ }^{2}$ yields a great deal of uniformity in terms of the settlement of awards and agreements.

Approximately 80 percent of the 263 documents settled by April 28, 1988 provided for wage increases of between 7 and 8 percent. Another 13 percent settled at between 8 and 9 percent. The full data is contained in Table 1 below. This dispersal is in line with what has generally been observed in a "usual" wage round. The pattern of wage increases certainly cannot be said to reflect the varying economic circumstances affecting different industries, regions and firms.

It should also be noted that where there were 'high' settlements, such as for drivers and for engineers at Nissan, this was often the result of significant changes to the bargaining structure.

New Zealand Employers Federation Report on Recent Wage Negotiations 1987-88 Wage Round as at Thursday, April 28, 1988.

While Employers Federation data does not cover all awards and agreements, including many in the State Owned Enterprises, other single employer agreements, and the maritime and other industries, it provides the most comprehensive data available until the Arbitration Commission's registration of documents negotiated in the round is completed later this year. This later data will provide significant insights into the nature and extent of changes to the bargaining structure. In particular, the extent to which composite bargaining has become more prevalent will be able to be assessed. 
Table 1: Analysis by size of wage increase

\begin{tabular}{lcc}
\hline Wage Increase & Frequency & Percent \\
\hline & 2 & 0.8 \\
6.00 percent to 6.5 percent & 2 & 0.8 \\
6.6 percent to 6.99 percent & 148 & 56.3 \\
7 percent & 33 & 12.5 \\
7.1 percent to 7.5 percent & 28 & 10.6 \\
7.6 percent to 8 percent & 17 & 6.5 \\
8.1 percent to 8.5 percent & 18 & 6.8 \\
8.6 percent to 9 percent & 6 & 2.3 \\
Over 9 percent & 9 & 3.4 \\
State linked & &
\end{tabular}

Similarly, Table 2 below shows little variation in settlements relating to allowances and other conditions of employment. The only changes of any significance appear to have taken place in the "service allowance" and "other conditions" categories.

Table 2: Changes in conditions

\begin{tabular}{lcc}
\hline \multicolumn{1}{c}{ Conditions Legend* } & $\begin{array}{c}\text { Numbers } \\
\text { Changed }\end{array}$ & $\begin{array}{c}\text { Percentage of } \\
\text { Total Settlements }\end{array}$ \\
\hline Service allowance increased/restructured & 27 & 10.2 \\
Registration payment increased & 1 & 0.4 \\
Meal money increased & 7 & 2.7 \\
Shift allowances increased & 1 & 0.4 \\
Indentureship allowances increased & 4 & 1.5 \\
Penal payment changes & 3 & 1.1 \\
Industry allowance inserted/increased & 11 & 4.2 \\
Increased sick pay entitlements & 15 & 5.7 \\
Regional/sector variations & 0 & 0 \\
New qualification payment & 1 & 0.4 \\
Other significant changes in conditions & 39 & 14.8
\end{tabular}

*NB: "Increased" means increased more than wages.

Other information of interest that may be gleaned from the data is that 28 or 10.6 percent of the documents contained pass-on memoranda and that 12 or 4.6 percent of the documents were either the result of restructuring, or there was agreement to restructure the award or agreement. In addition, there were 18 cases where the parties agreed to establish a working party to address certain issues that had arisen out of the negotiations. These are the areas where specific analysis will provide the best measure as to the nature and extent of changes to the bargaining structure. 


\section{Implications for the structure of bargaining}

Despite the limitations in the data, and given that a full analysis will only be possible once registration of all awards and agreements in this round has taken place, certain observations may be made. The first relates to the general level of wage settlement reached of around 7-8 percent. I have already outlined the hypothesis that unions were prepared to make the sacrifice of a "moderate round", especially given the depressed state of many industries, in return for the retention of national awards, at least for one year. This would also serve to give themselves time to prepare their strategies over the structure of awards and agreements in the longer term. Similarly, employers appeared prepared to accept the retention of the national award system, at least in this round, provided the costs of settlement could be borne by the large majority of employers subject to the award.

It is important in this context to contrast the inflationary expectations of the parties at the time what proved to be the "going rate" was negotiated, with the level of inflation that is now expected to occur over the duration of the awards and agreements negotiated. Inflation levels are important to both parties because they determine on the one hand for workers, whether their real wages will be maintained and on the other hand for employers, whether their real labour costs will increase or decline. While it is the producers' price index which is more relevant to employers' real costs, rather than the consumers' price index, which relates more closely to workers' real incomes and which is analysed here, the two indices generally move fairly much in tandem.

Many commentators and actors in the system argue that wages would better reflect changes in the demand for and supply of labour if they were set according to changes in unit labour costs, rather than merely changes in the economy generally. Unit labour costs are labour costs per unit of output produced. They are therefore calculated by dividing the total cost of labour by the number of units of output and are thus strongly related to productivity. While there are sound economic arguments to justify this position, levels of productivity vary so much from firm to firm and industry to industry that it is very difficult to bring such considerations into the national award framework. Therefore, it is the question of real wages and labour costs that is analysed here.

The New Zealand Metal Trades Employees Award was the first major award to settle, on 9 September 1987, and this was at the 7 percent level. This was to set the floor for the 7-8 percent average settlement. Clearly, however, preparation for the round had commenced well before this date. The Government had presented its commentary on the economic environment and the outlook for the forthcoming wage round on June 29, 1987. It highlighted the consequences of unrealistic settlements in the round and indicated that inflation was expected to decline sharply in the December quarter to reach around 7-9 percent for the year to March 1988. However, it was also estimated that the underlying inflation rate (allowing for the impact of GST) was approximately 12 percent for the year ended March 1987.

Measured inflation, however, reached a peak in the year ended June 1987 of 18.9 percent. The President of the Federation of Labour reacted to this announcement by arguing for significant wage increases to offset consumer price increases, while the Employers Federation considered negotiations should be forward looking and reflect the tight economic situation. This reflects a dilemma in wage bargaining; namely the extent to which adjustments are prospective or retrospective. In any event, such an unexpectedly high level of recorded inflation is very likely to have affected the parties' approach to wage bargaining, for the reasons given above.

The National Bank, in its 'Business Outlook', publishes the results of a monthly survey on inflationary expectations, amongst other things. The survey respondents are principally from small to medium size businesses, thus providing a reasonable crosssection of the New Zealand business community. It covers the retailing, manufacturing, transport, construction and farming sectors. Union coverage is strong in all but the first and last of these sectors. Table 3 compares the annual inflationary expectations of 
respondents (made one year earlier) and recorded inflation from February 1987 to April 1989.

Table 3: Expected inflation (surveyed one year previously) compared with recorded inflation

\section{Year Ended $\quad$ Expected Inflation (Percent) Recorded Inflation (Percent)} (Consumer Price Index)

$\begin{array}{lr}\text { February } 1987 & 16.3 \\ \text { March } 1987 & 15.3 \\ \text { April } 1987 & 13.7 \\ \text { May } 1987 & 13.5 \\ \text { June } 1987 & 12.7 \\ \text { July } 1987 & 12.7 \\ \text { August } 1987 & 13.1 \\ \text { September } 1987 & 13.2 \\ \text { October } 1987 & 13.8 \\ \text { November } 1987 & 13.7 \\ \text { December } 1987 & 13.9 \\ \text { February } 1988 & 14.4 \\ \text { March } 1988 & 14.1 \\ \text { April } 1988 & 14.0 \\ \text { May } 1988 & 12.9 \\ \text { June } 1988 & 12.5 \\ \text { July } 1988 & 12.2 \\ \text { August } 1988 & 12.9 \\ \text { September } 1988 & 12.6 \\ \text { October } 1988 & 13.3 \\ \text { November } 1988 & 12.2 \\ \text { December } 1988 & 11.8 \\ \text { February } 1989 & 10.2 \\ \text { March 1989 } & 10.0 \\ \text { April 1989 } & 9.2 \\ \end{array}$

The table highlights the volatility of inflationary levels as the effects of GST work their way through the system and the 'stickiness' of inflationary expectations.

Of equal interest, in terms of the real wage outcomes of the round, are the present projections for inflation in the years ending June and September 1988, which are 7.0 percent for June and an even lower figure for September. The implications flowing from the latter figure, which approximately accords with the term of many awards and agreements are that, on average, settlements will have resulted in the maintenance of, or perhaps even improvements in, workers' wages in real terms. Similarly, the average cost of wages to employers will have risen, or at least stayed at the same level, relative to other costs facing employers over this period.

This has therefore meant that any trade-off between a "low" wage round and deferring action on the restructuring of bargaining arrangements, which may have been either definitely or implicitly agreed on, has not actually occurred in practice. It is important to note here that when the 7 percent "wage path" was set, annualised inflationary expectations were at about 12.5 percent, 5.5 percent above the wage path. This fact must, 
however, be offset by the extent to which any retrospective adjustment to wage levels, which might otherwise have been agreed on, was foregone. This was why the metal trades settlement was described by commentators at the time as "very constructive" and "relatively modest". 3

For employers there are two obvious implications that follow from this result. One is that employers have not received the expected benefit of reduced real wage costs. Therefore those employers who were experiencing lower levels of profitability (i.e. many of those in the 'lower quartile') will have found these costs particularly difficult to absorb. The second is that support for a greater decentralisation of bargaining from union members who have the industrial strength to demand higher than average settlements will be lesser, given that they have been able to maintain or better their positions under what in essence remains the national award system, when implicitly such strategies were expected to see them worse off. Those workers' positions would be further protected where pass-on memoranda were agreed to, given that such workers will have been receiving above-award rates in the past.

From the union perspective, they have succeeded, to a very great extent, in maintaining the national award system for the 1987-88 wage round. This deferral of changes to bargaining arrangements allows them time to better assess their future options and strategies for the structure of bargaining under the new legislation. In addition, they have probably at least maintained (if not perhaps improved) the real wages of the vast majority of their members. Such a result is likely to only further defer structural change to bargaining arrangements, it is argued.

It should also be noted that inflationary expectations tend to follow the direction of recorded inflation. This is illustrated, for example, by significant declines in inflationary expectations for the years ending May 1988 and February 1989, following recorded falls in inflation, and by an increase for the years ending February 1988 and August 1988, after recorded increases. Inflationary expectations now appear to be falling quite rapidly. The most recent forecast (for the year ending April 1989) was down at 9.2 percent, and that was before the announcement of the further decline in recorded inflation for the year ended March 1988. The latest predictions for recorded inflation for the year ended June 1988 are about 7 percent, as the annual figures will by then not include the high 3.3 percent quarterly increase in the June 1987 quarter. This figure will be announced during the period wage negotiators are preparing for the forthcoming round and should thus further reinforce the downward trend in inflationary expectations. This in turn should result, all other things being equal, in lower average wage settlements than might otherwise have been the case. To the extent that wage increases feed through into increased costs, such moderate settlements will further assist the Government's anti-inflationary strategy.

However, despite the rapid fall in inflation and inflationary expectations, the respondents to the National Bank survey are still predicting inflation in a year's time to be higher than recorded levels for the past year. Commentators in this field have, for at least the last year, consistently forecasted lower levels of inflation than those predicted by the respondents to the survey, who are mainly made up of small and medium-sized businesses. It may be that such businesses do not have the resources or expertise to spend on inflation forecasting, but that does not derogate from the fact that "expert" opinion has been widely and freely available, but has been discounted to some extent. The most likely explanation for this 'stickiness' in expectations is scepticism over the ability of any New Zealand Government to successfully institute an enduring programme of disinflation. Given New Zealand's poor record in terms of inflation over the past fifteen or so years, such scepticism should surprise no-one. For this reason, settlements in the forthcoming wage round may again be above those that may have been reached given perfect knowledge by the bargaining parties. However, to attempt to attribute blame for this state of affairs to 
the negotiating parties, despite the fact that under the Labour Relations Act they are totally responsible for their own bargains, would be facile.

\section{Conclusion}

The Labour Relations Act has not been in force for sufficient time to assess whether its provisions will lead to the negotiation of awards and agreements which are relevant to the industry or workplace in which they apply. Whether this occurs or not is dependent largely on the attitudes of the bargaining parties. To the extent that unions ignore the need for wages to be more closely related to productivity and the differing positions of workers in different firms, industries and regions, and employers remain reticent to share information and to accept that their own workers and their respective unions have a participatory role to play in their enterprises, then such flexible and relevant settlements will be limited in number. Such a situation would ensure the maintenance of a slow adjusting, low-wage, low-productivity labour market and hence an underperforming economy.

The results of the first wage round under the Act showed that both unions and employers appeared prepared to accept a strategy that for unions would provide the continued aegis of the national award system and for employers would deliver moderate wage settlements. However, the rapid fall in inflation since September 1987 will probably mean that the level of workers' real wages will be maintained, over the round, rather than lowered as may have been expected. In terms of bargaining arrangements, this result is therefore likely to reduce the pressures on workers and their unions to accept change in bargaining structures. Thus the effect of inflation and inflationary expectations over the 1987-88 wage round may be to defer structural changes in bargaining, at least in some industries and occupations. However, this result need not necessarily prejudice the ability of the parties to develop, in time, mutually beneficial bargaining structures which can generate a more responsive labour market and enhanced economic outcomes.

\section{References}

Brosnan, Peter (1988) Wage rates still flexible New Zealand financial review 29 January 1988.

Federation of Labour and Combined State Unions (1987)1987 Tripartite wage conference statement of position, June 1987.

National Bank Business outlook March 1986 - May 1988 editions.

New Zealand Business Roundtable (1988) Labour markets and employment, April 1988.

New Zealand Employers Federation (1987) State of the economy New Zealand Employers Federation paper for the 1987 Tripartite wage conference, 29 June 1987.

New Zealand Government (1987) Government briefing to the 1987 Tripartite wage conference: economic commentary, July 1987.

New Zealand Government (1986) Government policy statement on labour relations, September 1986.

New Zealand Government (1987) Collective bargaining in New Zealand - recent trends and problems. Unpublished paper delivered to International Labour Organisation's 
Symposium on collective bargaining in industrial market economy countries, Geneva 2-6 November 1987.

The Treasury (1987) Government management brief to the incoming Government 1987, volume 1. 


\section{RELATIONS INDUSTRIELLES INDUSTRIAL RELATIONS}

Revue trimestrielle bilingue publiée par le Département des relations industrielles de I'Université Laval, Québec, Canada - A quarterly bilingual Journal published by the Département des relations industrielles, Université Laval, Québec, Canada. Directeur -Editor: Gérard Dion.

\section{SOMMAIRE - CONTENTS}

volume 43 , numéro 2,1988

La nouvelle Commission québécoise des relations du travail (1988)

Yves W. BRUNET, LUC BEAULIEU, Isabelle CANTIN

The New Québec Labour Relations Board (1988)

Canadian Labour Relations Under the Charter: Exploring the Implications Donald D. CARTER

Les relations professionnelles au Canada sous le régime de la Charte des droits

La productivité des intelligences André CAMIRÉ

Brain Efficiency and Organizational Productivity

Some Effects of Unemployment on the Health of Unemployed Quebec Workers Lee SODERSTROM

Quelques effets du chômage sur la santé des travailleurs sans emploi au Québec

Unions and Technology: A Survey of Union Use of Information Technology Andrew TEMPLER and Norman SOLOMON

Enquête sur l'utilisation de l'informatique par les syndicats dans leur administration

A Union Member's Perspective on Technological Change

Bart CUNNINGHAM and Denis HULL

Le point de vue d'un syndiqué sur les changements technologiques

Temps supplémentaire et création d'emplois: les cas du Canada, du Québec et de I'Ontario

Nawal KAMEL et Paul-Martel ROY

Overtime and Job Creation: An Application to Canada, Québec and Ontario

Mediation as a Conflict-Solving Device in Collective Industrial Disputes Berndt KELLER

La médiation comme moyen de résoudre les différends industriels collectifs

Décisions rendues par le Conseil canadien des relations du travail Johane TREMBLAY

Changements dans les législations du travail au Canada Michel GAUVIN et Geoffrey BRENNAN

Recensions - Book Reviews

Publications récentes - Recent Publications

Livres reçus - Books Received

Abonnements annuels - Annual Subcriptions - Institutions: \$48.00; Individus - Individuals: Canada, $\$ 24.00$ Etranger - Foreign: \$26.00. Le numero - Single Issue \$7.00 - Les Presses de I'Université Laval, C P 2477 Québec, Qué, Canada, GiK 7R4 